\title{
BETINGET DOM
}

\author{
Af Per Lindegaard
}

En sammenligning mellem de nordiske landes kriminalstatistikker er vanskelig. Det er forsøgt i den delbetænkning om alternativer til frihedsstraf, som nylig er afgivet af Nordisk Strafferetskomité, navnlig med henblik på at konstatere, om der er påfaldende forskelle i sanktionsanvendelsen mellem de nordiske lande. Resultatet af undersøgelsen er, at det ser ud, som om der er væsentlige variationer med hensyn til antallet af idømte frihedsberøvende sanktioner pr. 100.000 indbyggere. Sverige ligger lavest. Her var antallet i 1977 160. De tilsvarende tal for Danmark og Finland var 273 og 296. For Norge anslås det at ligge på ca. 230. Denne opgørelse angår alle arter af lovovertrædelser. Udskilles særlovsovertrædelser, således at kun overtrædelser af straffeloven (brottsbalken) bliver tilbage i sammenligningsgrundlaget, indsnævres forskellene. Antallet af idømte frihedsberøvende sanktioner for straffelovsforbrydelser var i Danmark, Norge og Sverige i 1977 henholdsvis 108, 89 og 84. Den større forskel i de totale tal antages derfor navnlig at være udtryk for en forskellig praksis med hensyn til de straffe, der idømmes i anledning af færdselslovsovertrædelser og herunder navnlig kørsel efter indtagelse af spiritus. ${ }^{1}$ )

Et af de vigtigste alternativer til idømmelse af en frihedsberøvende sanktion er betinget dom, enten alene betinget af straffrihed i en prøvetid (villkorlig dom) eller tillige forbundet med vilkår om tilsyn, eventuelt også særlige vilkår (skyddstillsyn).

På dette område var der vist tidligere forskelle i praksis mellem Sverige/ Norge på den ene side og Danmark på den anden. Emnet blev diskuteret på et møde i Dansk Kriminalistforening i $1969^{2}$ ), hvor det blev forelagt af en dansk forsvarsadvokat. Gæster fra Norge og Sverige gav i debatten udtryk for undren overfor den ret restriktive praksis, der fulgtes her i landet, navnlig med hensyn til anvendelse af betinget dom for arbejdspladstyveri. Siden da er der sket en udvikling i praksis i retning af en videregående anvendelse af betinget dom. I en artikel i Ugeskrift for Retsvæsen B 1970. 175 mente jeg på grundlag af en gennemgang af Højesteretspraksis indtil februar 1970 at kunne spore en begyndende tendens til udvidelse af området for betinget dom. I en artikel U 1973 B. 137 blev udviklingen i de følgende 3 år undersøgt, og den syntes at bekræfte den tidligere fremsatte formodning. 
Denne udvikling havde også afspejlet sig i tallene for andelen af betingede domme i det samlede sanktionsmønster:

(mænd - straffeloven)

Bøde

Påtalefrafald

Betingede domme

Ubetinget straf

(herunder komb. dom med frihedsstraf)
1970

$15 \% \quad 30 \%$

$27 \% \quad 15 \%$

$22 \% \quad 24 \%$

På det tidspunkt, da denne artikel blev offentliggjort, havde Folketinget gennem nogen tid behandlet et forslag om ændring i straffeloven særligt med henblik på mindre berigelsesforbrydelser. Dette forslag blev gennemført ved 1. 319 13.6. 1973, der trådte i kraft d. 1. 7. 1973. Ved loven nedsattes normalstrafferammen for berigelsesforbrydelser til 1 år, 6 mdr., i gentagelsestilfælde 2 år, 6 mdr., og der skete ændringer med hensyn til beskrivelsen af mindre strafværdige berigelsesforbrydelser, som åbnede for et videre anvendelsesområde af bestemmelsen herom, hvis strafferamme er begrænset til bøde og hæfte. Nok så væsentligt i den foreliggende sammenhæng var måske nok, at der under rigsdagsbehandlingen af lovforslaget blev givet udtryk for ønskeligheden af en videre anvendelse af betinget dom.

Siden 1973 er kriminalstatistikkens andel af betingede domme imidlertid ikke undergået nogen væsentlig ændring. Den har svinget mellem $23 \%$ (1977) og 26\% (1974), medens andelen af ubetinget frihedsstraf har varieret mellem 29\% (1974) og $27 \%$ (1976 og 1977). Dette modsiger i sig selv ikke, at området for anvendelse af betinget dom er blevet udvidet i praksis.

En gennemgang af trykt praksis i årene fra 1973 til udgangen af 1980 tyder på, at der er sket en udvikling med hensyn til betinget dom, som bl. a. har inddraget sagstyper, der tidligere kun sjældent lod betinget dom komme i betragtning som sanktionsmulighed.

Et område, hvor praksis i Danmark tidligere måske mest markant skilte sig ud fra praksis i andre nordiske lande var som omtalt tyveri fra arbejdsplads, hvor betinget dom forhen krævede en særlig begrundelse ${ }^{4}$ ). Med hensyn til denne gerningstype er der stilfærdigt sket en udvikling i praksis, der rækker ud over den, der betinges af inflationen i pengeværdien ${ }^{5}$ ). Som eksempler på seneste Højesteretspraksis refereres nedenstående domme, der antyder grænseområdet for betinget dom i disse sager $\left.{ }^{6}\right)$.

\section{U $1976.692 \mathrm{H}$ :}

Igennem nogle år var der sket omfattende tyverier på et københavnsk bryggeri, hvor bryggeriets salgschauffører havde stjålet øl til en samlet værdi af ca. 430.000 
kr. (incl. afgift). De havde samarbejdet med (og bestukket) virksomhedens portvagter, der skulle føre kontrol med læssene. 9 af chaufførerne havde stjålet for mellem 20- og $40.000 \mathrm{kr}$. En del af det stjålne øl var anvendt til repræsentation overfor kunder for at fremme salget. Deres direkte personlige udbytte antoges derfor kun at have været på 5-9.000 kr. De var ophørt med tyverierne nogen tid før anmeldelse blev indgivet. Ved opklaringen var de blevet afskediget, men fraset én havde de alle - delvis efter en længere arbejdsløshedsperiode — fået arbejde påny, da sagen kom til endelig pådømmelse.

Ved byretten var de blevet idømt ubetinget fængselsstraffe fra 3-6 måneder.

Ved landsrettens dom et halvt år senere blev straffene gjort betingede under henvisning til de tiltaltes personlige forhold. Dette blev også resultatet ved Højesterets dom et halvt år senere.

Alle dommere i Højesteret var enige om, at omfanget og beskaffenheden af de af de tiltalte på deres arbejdsplads forøvede tyverier som almindelig regel må udelukke anvendelse af betinget dom.

3 dommere voterede for betinget dom under henvisning til de tiltaltes personlige forhold, herunder de foran nævnte forhold.

2 dommere fand ikke, at de af flertallet anførte omstændigheder vedrørende de tiltaltes personlige forhold kunne bringe det almindelige synspunkt til at vige i den foreliggende sag og voterede for ubetinget straf.

\section{U $1978.469 \mathrm{H}$ :}

En 40-årig ustraffet tiltalt havde - efter tilskyndelse af en anden - på sin arbejdsplads, et lager, ad flere gange gennem en periode på 3 måneder stjålet varer til en værdi af ca. $90.000 \mathrm{kr}$., som var blevet afsat gennem den, der var fremkommet med opfordringen til at stjæle. T.s eget udbytte var opgjort til $7-8.000$ kr. T. var gift med 3 børn i alderen 6-13 år og hævdede, at han på gerningstiden havde haft ægteskabelige vanskeligheder, men at de ægteskabelige forhold nu var stabiliseret Ved byretten idømt 4 måneders fængsel, der blev gjort betinget under henvisning til hans personlige forhold. Tillige idømt en bøde på $800 \mathrm{kr}$. Denne dom stadfærstedes af landsretten (der dog udmålte straffen til 6 måneder). Ved Højesterets énstemmige dom ansås han med fængsel i 6 måneder ubetinget under hensyn til omfanget og beskaffenheden af de af $\mathrm{T}$ begåede tyverier på arbejdspladsen.

\section{U 1978.471 H:}

En chauffor, der var ansat på en virksomhed, der bl. a. fremstillede grammofonplader og kassettebånd, havde over en periode på ca. 3 år stjålet varer til en samlet udsalgspris på ca. $400.000 \mathrm{kr}$., som han havde solgt på værtshuse og arbejdspladser med et udbytte på ca. $100.000 \mathrm{kr}$. Ifølge T.s forklaring var han kommet ind på tyverierne på grund af udgifter til medicin og lægehjælp m. m. til hans hustru, der var syg og forfalden til medicinmisbrug.

Ved byretten blev T, der havde været i varetægt i 20 dage, idømt fængsel i 10 måneder ubetinget. Ved landsretten, hvor det var oplyst, at T var arbejdsløs, men 
desuagtet afbetalte $50 \mathrm{kr}$. ugentlig til det bestjålne firma, blev straffen under henvisning til den særlige baggrund for tyverierne, der ophørte ved hustruens hispitalsindlæggelse, gjort betinget. I Højesteret voterede 3 dommere efter omfanget og beskaffenheden af de af $\mathrm{T}$ gennem et langt tidsrum begåede tyverier for ubetinget straf, men nedsatte den under henvisning til de særlige forhold til 6 måneder. 2 dommere fandt, at der i den foreliggende sag havde været en sådan særlig baggrund for tyverierne, at det var forsvarligt at anvende betinget straf.

Indbrudstyvcrier gav for år tilbage kun sjældent anledning til at overveje betinget dom, hvis ikke gerningsmanden hørte til i de yngre aldersklasser. I reglen vidner indbrudstyverier om en større kriminel energi end f.eks. arbejdspladstyveri og andre former for simpelt tyveri. Indbrudstyveri har ofte et vist professionelt præg og begås hyppigt af personer, der har en større eller mindre kriminel belastning. Det er vel bl. a. overvejelser af denne karakter, der har ført lovgivningerne til at lade indbrudsvis udførelse være et element, der kendetegner et tyveri som $\operatorname{groft}^{\tau}$ ). Et materiale af betingede domme fra $1978^{8}$ ) viste imidlertid, at mere end halvdelen af de mandlige kriminelle, der var idømt betinget straf for tyveri, havde gjort sig skyldig i indbrudstyveri. Blandt de største værdier i opgørelsen over betinget dom for tyveri dominerede indbrud, men der var - ikke overraskende - en overvægt af lovovertrædere under 20 år blandt gerningsmændene til disse indbrud, der var resulteret $\mathrm{i}$ betinget dom. Af de senere års trykte afgørelser om betinget dom vedrører en ikke ringe del indbrudstyveri. Som eksempler kan nævnes ${ }^{9}$ ):

\section{U 1974.703 H:}

En 20-årig mand, der som 19-årig var straffet for vold med dagbøder, havde tildels sammen med en anden gjort sig skyldig i 25 indbrud og indbrudsforsøg hovedsagelig i forretninger med et udbytte på ca. $45.000 \mathrm{kr}$. Han var blevet pågrebet under det sidste indbrud og havde været undergivet varetægt $\mathrm{i}$ en måned. Om hans personlige forhold var det oplyst, at han levede sammen med en pige, hvis barn han var fader til.

Byretten fastsatte straffen til fængsel i 1 år, men gjorde den betinget med vilkår om tilsyn. I landsretten fandt et flertal på 5 dommere, at $\mathrm{T}$ under hensyn til omfanget og grovheden af hans kriminalitet, burde idømmes en ubetinget straf, medens 1 dommer voterede for stadfæstelse. Denne dom ankede $\mathrm{T}$ til Højesteret til formildelse, anklagemyndigheden til skærpelse. Højesteret henførte forholdet under strfl. $\$ 286$ (grov berigelseskriminalitet) under henvisning til, at flere af forholdene vedrørte pengeskabstyveri og forsøg derpå samt forholdenes antal og karakter, og fastsatte straffen til ubetinget fængsel 1 år af de $\mathrm{i}$ landsrettens dom anførte grunde. 
U $1976.357 \mathrm{H}$ :

Den 40-årige $\mathrm{T}$ havde sammen med andre $\mathrm{i}$ to tilfælde gjort sig skyldig $\mathrm{i}$ indbrud med et udbytte på ialt ca. $1.000 \mathrm{kr}$. T var tidligere straffet talrige gange for berigelseskriminalitet senest i 1960, hvor han var blevet idømt forvaring, men der forelå ikke oplysninger om kriminalitet siden løsladelsen i 1963.

I byretten og landsretten var han blevet idømt ubetinget straf, men ved Højesterets dom blev straffen gjort betinget. Det var oplyst, at han efter et ophold i udlandet på 2 år nu påny havde bosat sig i Danmark og havde giftet sig, og at der var et barn i ægteskabet. Siden sin tilbagekomst havde han haft fast arbejde. På baggrund af disse oplysninger og den lange tid, der var gået siden den senest forudgående kriminalitet, fandt 3 dommere det ikke påkrævet, at straffen kom til fuldbyrdelse og gjorde frihedsstraffen betinget med en tillægsbøde på $2.000 \mathrm{kr} .2$ dommere votcrede for stadfæstelse.

Traditionelt anlægges en mere overbærende holdning overfor underslab, hvis udførelse jo kræver en beskeden kriminel energi, og i hvis tilblivelse der ofte nidgår et fristelsesmoment, og betinget dom anvendes i vidt omfang overfor denne form for kriminalitet, afhængig af størrelsen af det underslæbte beløb, genoprettelsen af skaden og de nærmere omstændigheder ved forøvelsen, herunder om der foreligger brud på et særligt pligtforhold. Når opdagelsen har ført til afskedigelse fra tjenestemands- eller lignende stilling eller rettighedsfratagelse, synes retterne i stigende omfang i de senere år at have anvendt betinget dom, også når krænkelse af særlige pligtforhold foreligger ${ }^{10}$ ). Som eksempler på domme om underslæb nævnes:

\section{U 1978.750 Ø:}

En advokat havde gjort sig skyldig i underslæb ved uberettiget forbrug af ca. $37.000 \mathrm{kr}$., som han ved en fejltagelse havde modtaget af en kollega. Han havde tillige medvirket til, at nogle klienter havde gjort sig skyldig i skyldnersvig overfor et bctalingsstandsningsbo ved at oprette et antedateret dokument, således at der sikredes klienterne separatiststilling med hensyn til en vareleverance for ca. $150.000 \mathrm{kr}$. Forholdene kom først til pådømmelse ca. 3 år efter, at de var begået, og forinden havde advokaten dækket underslæbet. Under hensyn hertil og til at der ved dommen blev truffet bestemmelse om frakendelse for bestandig af retten til at drive advokatvirksomhed, gjorde byretten straffen, fængsel 1 år, betinget. $\mathrm{T}$ ankede til frifindelse, subsidiært til formildelse, anklagemyndigheden til skærpelse, men ved Østre Landsret blev dommen stadfæstet, idet retten navnlig lagde vægt på rettighedsfrakendelsen som begrundelse for at stadfæste den betingede dom. 
U 1981.846 H:

I U 1981.361 vedrørende underslæb til et beløb af ca. $180.000 \mathrm{kr}$. fastsatte Højesteret straffen til fængsel i 1 år, hvoraf 9 måneder gjordes betinget henset til oplysningerne om den tiltaltes personlige forhold.

I en dom afsagt den 28. august 1981 har Højesteret påny taget stilling til spørgsmålet om anvendelse af en helt eller delvis betinget retsfølge i forbindelse med underslæb med hensyn til et beløb af samme størrelsesorden begået under lignende omstændigheder. Resultatet i denne sag blev en ubetinget straf.

Sagen angik en 38-årig bogholder og kasserer, der efter 2 måneders ansættelse på et vaskeri over en periode på ca. 2 år tilegnede sig ca. 170.000 kr. Pengene anvendtes til privat forbrug. Tiltalte forklarede underslæbet med dårlig økonomi på grund af huskøb og hendes mands sygdom og arbejdsløshed. Ingen del af beløbet var tilbagebetalt.

Tiltalte, der havde 2 hjemmeboende børn under uddannelse, som ved sagens pådømmelse i Højesteret var 16 og 18 år, hævdede under sagen, støttet af kriminalforsorgen, at en ubetinget retsfølge formentlig ville medføre ægteskabets opløsning.

Ved byrettens dom blev tiltalte idømt fængsel i 1 år, der, »uanset at der er tale om undersiæb til et større beløb og begået over en lang periode over for tiltaltes arbejdsgiver «, gjordes betinget under hensyn til »de om tiltaltes personlige forhold foreliggende oplysninger samt tiltaltes forklaring om begrundelsen for det strafbare forholds begåelse«. Landsretten ændrede til ubetinget straf under henvisning til størrelsen af beløbet og længden af det tidsrum, hvori lovovertrædelsen var begået.

Fra anklagemyndighedens side blev det under sagens behandling i Højesteret navnlig gjort gældende, at det efter forarbejderne til straffelovens $\$ 58$ om kombinationsdom måttc antages, at denne bestemmelse ikke tog sigte på tilfælde som det foreliggende.

Højesteret stadfæstede Vestre Landsrets dom med bemærkning, at der »efter forbrydelsens omfang og beskaffenhed ikke i tiltaltes personlige forhold findes grundlag for at gore straffen eller nogen del heraf betinget«. 2 dommere stemte navnlig under hensyn til udfaldet af den tidligere dom (U 1981.361) for at nedsætte straffen til fængsel i 6 måneder.

I disse to højesteretsdomme afspejler konflikten mellem generalpræventive hensyn og dommens konsekvens for den enkelte lovovertræeder sig tydeligt. I sager om socialbedrageri og lignende bedrageriske forhold, hvor der ved bibringelse eller under udnyttelse af en vildfarelse opnås uberettigede ydelser, har generalpræventionen traditionelt haft overvægt. Til forskel fra almindelige bedragerier er den, der yder, i disse tilfælde forpligtet til at levere sin ydelse, og det vil ofte være vanskeligt at efterprøve de oplysninger, der præsenteres af modtageren. I disse sager er der derfor regelmassigt også strafansvar for afgivelse af urigtig erklæring. Også på dette felt er der sket en lempelse i de senere år, men udfaldet afhænger selvsagt af 
en konkret bedømmelse både af omstændigheder, der belyser strafværdigheden, og den tiltaltes personlige forhold ${ }^{11}$ ).

\section{U $1974.702 \mathrm{H}$ :}

Arbejdsløshedskassebedrageri med hensyn til $2.300 \mathrm{kr}$.

Den 58-árige $\mathrm{T}$, der 10 år forud var straffet for dokumentfalsk med betinget dom, havde uberettiget ladet sig udbetale arbejdsløshedsunderstøttelse med det anførte beløb, idet han i en række tilfælde havde forevist kontrolkort for arbejdsløshedskassen, hvoraf det fremgik, at arbejdet var indstillet på grund af dårligt vejr. Kontrolkortenes arbejdsgiverbekræftelse af denne oplysning var falskeligt underskrevet af hans forlovede, som han under trusel om klø havde tvunget til at skrive under. For dokumentfalsk og urigtig erklæring idømt fængsel i 4 måneder, der blev gjort betinget i byretten. Landsretten ændrede til ubetinget straf på fængsel i 40 dage. Denne dom stadfæstedes ved en énstemmig Højesterets dom, der som begrundelse for ubetinget straf henviste til de nærmere omstændigheder ved forbrydelsens begåelse og T’s personlige forhold.

\section{U 1974.874 H:}

Den 25-ârige T modtog over en periode på 1 år hjælp fra socialkontoret med ca. $32.500 \mathrm{kr}$., idet han i 16 skriftlige erklæringer forsikrede, at han ingen indtægt havde. Dette var ikke rigtigt. Efter sande oplysninger om hans indtægt ville han kun have været berettiget til en mindre understattelse; ved de urigtige oplysninger havde han formået socialkontoret til at udbetale sig ca. $5.500 \mathrm{kr}$. for meget. Han blev for bedrageri og urigtig erklæring idømt en betinget straf på fængsel i 60 dage ved byretten. Landsretten ændrede afgørelsen til en kombinationsdom, 30 dage ubetinget +30 dage betinget. $\mathrm{T}$ ankede dommen til Højesteret. For Højesteret forelå der positive oplysninger om hans personlige forhold, og personundersøgeren gav udtryk for, at $\mathrm{T}$ i den kriminelle periode havde været ude $\mathrm{i}$ en krise, der havde resulteret $i$, at han gav efter for sin betrængte økonomi. I Højesteret voterede 4 dommcre for en straf på fængsel i 3 måneder, der blev gjort betinget med vilkår om tilsyn, idet man lagde vægt på oplysningerne om T.s nuværende stabile forhold. 3 dommere fandt under henvisning til omstændighederne ved det begåede forhold og størrelsen af det besvegne beløb, at der ikke burde anvendes betinget dom.

\section{U $1978.972 \mathrm{~V}$ :}

En 59-årig mand havde over en periode på 5 år formået en arbejdsløshedskasse til at udbetale sig ca. $95.000 \mathrm{kr}$. i arbejdsløshedsunderstøttelse, skønt han som udøver af selvstændig indtægtsgivende virksomhed ikke havde været berettiget til understøttelse. Beløbet var blevet dækket.

$\mathrm{T}$ idømtes fængsel i 8 måneder for bedrageri (urigtige erklæringer forelå ikke). men denne straf blev uanset beløbets størrelse og periodens længde gjort betinget, bl. a. under henvisning til at det måtte have været muligt og naturligt for arbejdsløshedskassen på et langt tidligere tidspunkt end sket at skaffe sig klarhed over T.s arbejdsforhold. 
Forsikringsbedrageri har lighedspunkter med socialbedrageri, men er farligere forsåvidt som forsikringsbedragerier kan udvikle sig til en halvprofessionel kriminalitetsform med bistand af betalte hjælpere. Der er oplysninger, der tyder på, at forsikringsbedragerier er tiltagende, og bl. a. dette er baggrunden for, at enkelte domme herom har været indbragt for Højesteret $\left.^{12}\right)$. Fra de senere år refereres nedenstående sager:

\section{U $1975.1062 \mathrm{H}$}

En 35-årig man havde den 13.5. 1972 oprettet en kaskoforsikring for sit motorkøretøj. Den 14. samme måned anmeldte han til forsikringsselskabet, at vognen var skadet og formåede selskabet til at udbetale sig en erstatning på $2.300 \mathrm{kr}$. Senere kom det frem, at skaden var indtrådt den 12.5. - før forsikringen var tegnet og forårsaget af ham selv. Desuden havde han gjort sig skyldig $i$ et mindre underslæb og falsk forklaring for retten om et spørgsmål, som var uden betydning for det forhold, der søgtes oplyst.

$\mathrm{T}$ blev mod sin benægtelse fundet skyldig, og byretten idømte ham en betinget straf + bøde $1.000 \mathrm{kr}$. Under henvisning til forholdenes karakter fandt landsretten, at der burde idømmes ubetinget straf. Denne dom andredes af Højesteret ved en énstemmig dom til betinget straf uden tillægsbøde.

\section{U $1975.1063 \mathrm{H}$ :}

$\mathrm{T}$, der drev en mindre erhvervsvirksomhed, anmeldte til sit forsikringsselskab, at der havde været indbrud i virksomheden, medens han var på week-end i Sverige, og at varelaget og pengebeholdningen var stjålet. På grundlag heraf fik han udbetalt ca. 30.000 kr., som blev indsat på hans bankkonto. Det var imidlertid T selv, der havde fået en anden til at bryde ind, og der var intet stjålet. For dette forhold og køb og omsætning af indsmuglede cigaretter og spiritus blev han ved byretten straffet med ubetinget fængsel i 6 måneder, idet retten efter arten af det begåede bedrageri og den tilsigtede økonomiske fordel ikke fandt, at betinget dom kunne anvendes. Landsretten fandt, at betinget dom efter T.s personlige forhold og beløbets tilbagebetaling burde anvendes, men fastsatte ved siden af en bøde for toldovertrædelsen. Ved Højesteret blev byrettens dom stadfæstet $\mathrm{i}$ henhold til dens grunde, dog således at straffetiden blev reduceret til 4 måneder.

\section{U $1979.373 \mathrm{H}$ :}

$\mathrm{T}$, der var 29 år og gentagne gange straffet for berigelseskriminalitet, var utilfreds med sin gamle bil. Efter sin forklaring mødte han en dag en gammel fængselskammerat, som han delagtiggjorde i sin misfornøjelse, hvortil kammeraten svarede: "Hvorfor ikke lave den til konfetti? « De fulgtes ad til en autoophugger, som mod overtagelse af vognen og betaling af et midre beløb påtog sig at hugge den op. $T$ anmeldte den derefter som stjålet til forsikringsselskabet, der erstattede den med ca. $52.000 \mathrm{kr}$. Knapt et år forinden var T prøveløsladt med en reststraf på 304 dage. Byretten fastsatte en fællesstraf, der omfattede reststraffen og straffen for forsik- 
ringsbedrageri og falsk anmeldelse, på 1 år, 3 måneders fængsel. På grundlag af en positiv erklæring fra Kriminalforsorgen om T.s uddannelsesplaner blev dommen gjort betinget med tilsynsvilkår. Denne afgørelse blev stadfæstet af landsretten efter de foreliggende særlige oplysninger om den stedfundne udvikling i T.s forhold. Ved Højesterets énstemmige dom blev $\mathrm{T}$ idømt en ubetinget straf af fængsel i 5 måneder for det aktuelle forhold, medens prøveløsladelsen under henvisning til oplysningerne om hans personlige forhold blev opretholdt.

I dansk ret bedømmes et bedrageri, der kvalificeres ved brug af falske dokumenter, alene som dokumentfalsk, ikke som bedrageri eller bedrageri i forbindelse med dokumentfalsk. Udenfor tilfælde, hvor dokumentet eller forfalskningen eller det, der søges opnået, har været af underordnet betydning, eller hvor forbrydelsen er begået uden skadehensigt, f. eks. for at afværge et uberettiget krav, er dokumentfalskforbrydelsen tidligere blevet anset som så alvorlig, at betinget dom kun ganske undtagelsesvis kom i betragtning. I de senere års praksis synes betinget dom anvendt noget hyppigere. Som eksempler nævnes $\left.{ }^{13}\right)$ :

\section{U 1973.673 H:}

Den nu 22-årige $\mathrm{T}$ var den 6.12. 1971 blevet idømt en betinget straf på fængsel i 5 måneder med tilsyn for bedrageri ved udstedelse af dækningsløse checks. 9 dage efter dommen begik han sammen med en anden indbrud $i$ en virksomhed, hvor de bl. a. stjal ca. 300 checkblanketter. I løbet af de følgende 14 dage udgav de 54 af checkblanketterne med pålydende ialt $14.000 \mathrm{kr}$., som de fik udbetalt efter at have underskrevet checkene med falske navne, og som legitimation benyttet et forfalsket pas og et forfalsket førerbevis.

Den tilsynsførende havde givet positive oplysninger om tilsynsforløbet og under henvisning hertil og til tiltaltes alder og det indtryk retten havde fået af ham, gav beretten en betinget straf på fængsel i 1 år med fradrag af 62 dage for varetægt. Landsretten ændrede straffen til ubetinget fængsel under henvisning til forbrydelsernes omfang og beskaffenhed, det hurtige kriminelle tilbagefald og de personlige oplysninger, der forelå om $\mathrm{T}$, og denne afgørelse blev stadfæstet af Højesteret.

\section{U 1975.446 V:}

To 20-årige kvinder, den ene forud straffet med dagbøder for tyveri, havde erkendt sig skyldige i dokumentfalsk ved at have hævet nogle checks, til et samlet beløb af ca. $63.000 \mathrm{kr}$., der var stjålet og forsynet med falske underskrifter af deres forlovede. De havde hver et nyfødt barn, den ene desuden et barn på 2 år. De forlovede. som de senere havde giftet sig med, var strafafsonere.

Byretten meddelte betinget dom under henvisning til det om deres personlige forhold oplyste. Denne dom stadfæstedes af landsretten, der fremhævede, at de strafbare forholds omfang og grove beskaffenhed talte for anvendelse af ubetinget 
straf, men landsretten fandt det dog forsvarligt at anvende betinget dom, idet man udover byrettens begrundelse henviste til deres alder, og at deres handlinger havde karakter af medvirken til andres lovovertrædelser.

U 1976.53* H:

Den 22-årige T, der var stævnet til betaling af en købmandsregning på $450 \mathrm{kr}$., fremlagde i retten købmandens regning, som han selv havde forsynet med falsk kvittering. $\mathrm{T}$ hævdede, at han mente at have betalt alt hvad han skyldte, da han blev rykket for de $450 \mathrm{kr}$. Byretten fastsatte straffen til fængsel i 30 dage, som blev gjort betinget med tilsyn. I landsretten delte stemmerne sig. 1 voterede for stadfæstcise, en anden for stadfæstelse + tillægsbøde, men 4 fandt ikke grundlag for at gøre dommen betinget. Højesteret lagde til grund, at $\mathrm{T}$ havde lavet forfalskningen for at befri sig for en gæld, han ikke mente at skylde. og henførte forholdet under $\$ 172$, stk. 2, der nedsætter strafferammen for dokumentfalsk, bl. a. når det foretages for at afværge et uberettiget krav. Med henvisning hertil stadfæstedes byrettens dom.

\section{U 1980.828 Ø:}

En 39-årig jugoslav, der havde opholdt sig i Danmark i 10 år, foreviste for skattemyndighederne $\&$ falskeligt opskrevne postkvitteringer for at dokumentere, at han havde krav på skattefradrag på dette beløb ifølge en kontrakt om forsørgelse af sine forældre i Jugoslavien.

Ved landsretten anset for skyldig i dokumentfalsk og skattesvig til $11.600 \mathrm{kr}$. Det var oplyst, at han på dommens tid havde været arbejdsløs i henved 1 år, og at hans hustru havde været arbejdsløs eller sygemeldt i $2^{1 / 2}$ år. Med referat af disse oplysninger stadfæstede landsretten byrettens betingede dom, men idømte ved siden af en ubetinget bødestraf på $5.000 \mathrm{kr}$.

Haleriforbrydelsen har en meget betydelig variationsbredde med professionel aftagervirksomhed i stor stil som det ene yderpunkt og tilfældig bistand til transport eller opbevaring som det andet. Praksis med hensyn til betinget dom afspejler vurderingen af strafværdigheden ${ }^{14}$ ). Fra denne praksis nævnes et enkelt eksempel, der repræsenterer et mellemtilfælde:

\section{U 1977.150 H:}

Som en udløber af en omfattende efterforskning, der omfattede ialt 71 personer, fandt politiet frem til nogle aftagere af stjålne koster, deriblandt en ustraffet købmand, der blev anholdt og undergivet varetægt i knapt 2 måneder. Han havde over en periode på ca. $1 / 2$ år på en tankstation købt stjålet pilsnerøl til en værdi af ialt ca. $20.000 \mathrm{kr}$., sammen med 2 andre 22 ægte tæpper til en værdi af ca. $80.000 \mathrm{kr}$. og alene et møblement til ca. $6.500 \mathrm{kr}$. Øllet havde han solgt i sin købmandsforretning, medens han havde beholdt møblementet og sin del af tæpperne. Byretten idømte en straf på 1 års fængsel, men fandt under henvisning til, at overtrædel- 
serne tildels havde haft en professionel karakter, ikke grundlag for at gøre straffen betinget. I landsrettens dom refereres, at T var gift og havde 2 børn på 5 og 8 år, $o g$ at hustruen var medhjælper i forretningen. Under hensyn hertil, den lange tid der var gáct siden lovovertrædelserne fandt sted og den udståede varetægt gjorde landsretten dommen betinget. Denne dom blev anket af anklagemyndigheden til Højesterct, hvis flertal stemte for at stadfæste byrettens dom under hensyn til omfanget og beskaffenheden af hælerierne, der angik varer, som tildels var videresolgt i T.s forretning. Én dommer voterede særligt undẹr hensyn til, at der på dommens tidspunkt var forløbet 3 år siden forholdene blev begået, for at stadfæste landsrettens dom.

Antallet af roverier er steget dramatisk gennem de senere år. I 1969 lå tallet for anmeldte røverier og røveriforsøg på ca. 300, i 1980 på $1485^{15}$ ). Antallet af bankrøverier (og forsøg) varierede i perioden fra 1970 til 1977 mellem 19 og 69 med 30-50 pr. år som det typiske. I 1980 var det samlede antal af bankrøverier 135. Væksten i denne kriminalitetstype tilsiger af generalpræventive grunde strenge reaktioner i de tilfælde, der gennemføres til fældende dom. Umiddelbart måtte man forvente, at betinget dom ville være en ekceptionel reaktion for røveri. En undersøgelse af et materiale, der består af samtlige fældende domme afsagt i 1977 (ialt 124), viste dog, at ren betinget dom var anvendt for 12 af ialt 185 domfældte $\left.{ }^{16}\right)$. Medtages betinget dom efter forudgående varetægt og kombinationsdomme (med højst 3 måneders ubetinget straffedel) vokser antallet med 33, således at betinget dom (incl. kombinationsdom) er anvendt for ialt $24 \%$ af de domfældte. Dette hænger sammen med aldersfordelingen i dette materiale. Andelen af domfældte, der ikke var fyldt 21 år på gerningstiden, udgjorde $55 \%$. Betinget dom synes anvendt i større udstrækning end en gennemgang af trykt praksis tyder på ${ }^{17}$ ). Fra trykt praksis fra de senere år, hvor der har været eller kunne være spørgsmål om betinget dom for røveri, anføres følgende domme:

\section{U $1977.609 \varnothing$ :}

En 65-årig mand havde gjort sig skyldig i bankrøveri, idet han lagde en seddel foran en bankkasserer, som indeholdt et forlangende om at få en plasticpose fyldt op med penge og en trusel om at skyde, men han foreviste ikke noget våben. Kassereren udleverede $5.500 \mathrm{kr}$. Byretten anså det for godtgjort, at $\mathrm{T}$ på gerningstiden var fysisk og psykisk nedbrudt og $\mathrm{i}$ en kritisk tilstand af mental uligevægt, og fandt derfor, at $T$ havde handlet under indflydelse af stærk sindsbevægelse eller lign., som begrundede strafnedsætteles efter straffelovens $\S 85$. Under hensyn hertil karakteren af røveriet, tiltaltes usikre forsæt og hans alder samt at han led af tuberkulose bestemte byretten straffen til en kombinationsdom ( 3 måneder ubetinget +9 måneder betinget). Landsretten tiltrådte, at $\mathrm{T}$ havde befundet sig $\mathrm{i}$ en 
tilstand, der var omfattet af strafnedsættelsesgrunden i $\S 85$, men fandt under hensyn til sagens alvorlige beskaffenhed, herunder særligt, at der var tale om et forud planlagt bankrøveri, at straffen burde forhøjes til fængsel i 2 år og gøres fuldstændig ubetinget.

U $1977.856 \mathrm{H}$ :

En 25-årig flere gange straffet mand, der kort forinden var løsladt fra en straf på fængsel i 8 måneder for tyveri m. v., indfandt sig forst $\mathrm{i}$ et ismejeri, og få minutter efter i en tobaksforretning i samme ejendom og forlangte penge, idet han ved at holde sin hånd under trøjen foregav at være i besiddelse af skydevåben. Begge forretningsindehavere nægtede at udlevere penge, og han måtte gå med uforrettet sag. T nægtede sig skyldig, idet han hævdede, at der var tale om en spøg. Han var påvirket af stesolidtabletter og vred over, at han kort forinden - efter sin egen opfattelse ved, at en bekendt »rullede« ham - havde mistet sine sko og sin jakke med penge.

I nævningetinget var han blevet idømt fængsel i 1 år ubetinget, og denne straf blev stadfæstet af Højesteret.

U 1978.2.47 Ø:

Den ustraffede 16-årige $\mathrm{T}$ havde ved nattetid udfor en sparekasse overfaldet en ung pige, der kom med 2 bokskassetter ialt indeholdende henved $7.000 \mathrm{kr}$., idet han to gange slog hende i hovedet med en træstav, hvorefter han tog kassetterne fra hende. Efter næsten 1 måneds varetægt afsagde byretten dom, der lød på 6 måneders ubetinget fængsel og betaling af en erstatning på $600 \mathrm{kr}$. til den unge pige. Inden dommen i landsretten var denne erstatning betalt. Under hensyn til T.s unge alder, det om hans personlige forhold oplyste og varetægtstiden blev straffen gjort betinget med vilkår om tilsyn efter bistandslovens bestemmelser om børn og unge.

Den danske straffelovs almindelige voldsbestemmelse indtager en særstilling blandt straffelovens regler, idet den meget udførligt - og måske for detaljeret - normerer de hensyn, der skal være bestemmende for strafudmålingen. Den fik sin nuværende skikkelse i 1939, og formålet med denne revision var især at begrænse domstolenes mulighed for at anvende bødestraf. Derimod lå tanken om at bruge betinget dom formentlig datidens retsanvendelse temmelig fjernt. I forbindelse med ændringen af straffeloven i 1973 (mindre berigelsesforbrydelser) blev der i justitsministeriets bemærkninger til lovforslaget ${ }^{18}$ ), peget på muligheden af betinget dom i sager, der ikke angik vold mod sagsløse, navnlig når der kunne være behov for afvænningsbehandling mod spiritusmisbrug, idet der henvistes til, at den fornødne intensitet $\mathrm{i}$ reaktionen kunne nås ved betinget dom kombineret med bøde og vilkår om erstatningsbetaling. De fleste gerningsmænd begår antagelig voldshandlingerne i spirituspåvirket tilstand, men det er formentlig 
de færreste af dem, der er forfaldne til spiritusmisbrug i den forstand, at de ikke kan beherske deres spiritusforbrug. Der har da heller ikke vist sig nogen eksempler i trykt praksis på betingede domme i sådanne tilfælde. Derimod er betinget dom i ret stor udstrækning anvendt overfor gerningsmænd under $21 \mathrm{a}^{19}$ ). Under en debat i Folketinget i december $1979 \mathrm{blev}$ der taget til orde for skærpede forholdsregler overfor voldskriminaliteten. Dette har ført til en lidt større nuancering af straffene $i$ den senere tids praksis og en begrænsning af anvendelsen af betinget dom i aldersklasserne over 18 år, hvor der synes at blive krævet en særlig begrundelse for at bruge betinget dom. Derimod anvendes betinget dom jævnligt overfor unge under 18 år, der gør sig skyldig i vold af ordinær karakter, i reglen forbundet med bøde. Nogle specielle tilfælde af vold i beskedent omfang, men forøvet i forbindelse med udøvelsen af offentlig tjeneste, har været prøvet ved Højesteret med det udfald, at straffen blev ubetinget, skønt det måtte ventes, at ubetinget straf ville føre til afskedigelse, U $1979.858 \mathrm{H}$ (fængselsbetjent og arrestforvarer) og U $1979.896 \mathrm{H}$ (politibetjent).

Som eksempel på en ordinær voldssag fra den seneste tid med unge gerningsmand refereres nedenstående $\operatorname{dom}^{20}$ ):

\section{U $1981.119 \mathrm{H}$ :}

3 unge mænd, de to 18 år, den tredie 17 år, alle ustraffede, havde været på kro og fået en del at drikke. På hjemturen i bil - der førtes af en fjerde - blev de irriterede på en 15-årig knallertfører, som kørte uden tændt baglygte. De bragte knallerten til standsning. Den ene af de 18-årige slog ham med knytnæve, de to andre slog og sparkede ham. Knallertføreren fik et mindre sår ved munden og et blåt øje.

Byretten fandt, at betingede straffe måtte være udelukket efter overfaldets karakter og idømte hæftestraffe fra 30-40 dage. Landsretten henviste til, at der forelå særdeles gode oplysninger om de tiltalte, og dette i forbindelse med deres unge alder motiverede landsretten til at gøre frihedsstraffene betinget, således at der i forbindelse hermed idømtes hver af de tiltalte en ubetinget bøde på 1.000 kr.

Denne dom stadfæstede Højesteret for den 17-årige, der var i lære og havde betalt en erstatning på $200 \mathrm{kr}$. til den overfaldne, medens de to andre idømtes ubetinget hæfte i 30 dage.

På seksualkriminalitetens område har der i de senere år været en ivrig betænkningsaktivitet, men de lovgivningsmæssige initiativer har været få. Både i Sverige og i Danmark er der fremlagt udkast om nedsættelsen af mindstealderen for frivilligt kønsligt samvær ${ }^{21}$ ), men de har ikke hidtil ført til lovændring. I Danmark, hvor mindstealderen er 15 år, har det været fast praksis i de sidste 20 år at frafalde tiltale mod mænd under 18 år, der havde 
haft samleje med piger over 14 år, når samlejet havde været fuldt frivilligt, og praksis er også gået ud over disse aldersgrænser. Holdningsændringer i forbindelse med ny indsigt har ført til en mere lempelig vurdering af homosexualitet; i Danmark er aldersgrænsen nu den samme for homosexuelt forhold som for heterosexuelt forhold ${ }^{22}$ ). De friere omgangsformer mellem kønnene har også indvirket på vurderingen af voldtægtsforbrydelsen. I 1967 gennemførtes ændringer af de danske voldtægtsbestemmelser, der utilsigtet - medførte en væsentlig mildere bedømmelse af voldtægtstilfælde, hvor der $\mathrm{i}$ forvejen havde bestået en kontakt mellem gerningsmanden og kvinden; i Sverige diskuterede Sexualbrottsutredningen samme problem. Denne betænkning har ikke ført til lovgivningsinitiativ, og på de sidste har vi oplevet en kvindereaktion, der tager bestemt afstand fra den udvikling ${ }^{23}$ ), som er sket i Danmark. En atypisk incestsag, hvor der i proceduren for Højesteret blev henvist til betragtningerne i Sexualbrottsutredningens betænkning, blev afgjort ved U $1981.40 \mathrm{H}$ med ubetinget fængsel 1 år.

Tiltalte, der ikke havde haft forbindelse med to tvillingdøtre siden de var $1-2$ år gamle, genoptog forbindelsen, da de var 14 år. Under et besøg hos $\mathrm{T}$ havde han samleje med den ene, der da var fyldt 15 år, og han forsøgte at opnå samleje med den anden, men undlod dette, da hun protesterede.

Som eksempler fra andre områder nævnes nedenstående domme ${ }^{24}$ ):

\section{U $1978.581 \emptyset$ :}

29-årig havde 3 gange haft samleje med 13-14-årig pige. Han havde boet sammen med pigens moder $\mathrm{i}$ et ægteskabslignende forhold, og pigen og de voksne havde haft fælles soveværelse; han var i den senere del af gerningstiden fraflyttet moderens hjem, men overnattede der stadig. Ved pådømmelsen kom han stadig sammen med moderen, og der var ikke uvenskab mellem ham og pigen. Han havde stabile arbejdsforhold. Ved byretten idømt betinget fængsel i 3 måneder, der blev stadfæstet af landsretten, men med 2 stemmer for ubetinget straf, idet disse dommere lagde vægt på, at $\mathrm{T}$ samlevede med pigens moder.

\section{U $1979.248 \varnothing$ :}

To 13-årige piger, som efter en annonce om fotomodeller henvendte sig hos en 32årig og 28-årig, der ikke tidligere var straffet, lod sig af dem bevæge til forskellige seksuelle forhold, herunder samleje med den ene og lod sig fotografere i nogle af disse situationer. Pigerne havde tidligere haft seksuelt samkvem med jævnaldrende drenge. Báde ved byretten og landsretten blev mændene idømt ubetinget straf, som landsretten fastsatte til fængsel i 4 måneder. Der fandtes ikke grundlag for betinget dom under henvisning til tiltaltes aldersmæssige overlegenhed, de seksuelle forholds art og til annonceringen. 
U 1976.868 Ø:

Knap 43-årig marokkaner, der var kommet til Danmark 6 år forinden som fremmedarbejder, havde haft et enkelt samleje med en knap 14-årig pige, der besøgte ham på hans værelse. Under hensyn til den store aldersforskel 3 måneders fængsel ubetinget ${ }^{25}$ ).

\section{U 1980.468 Ø:}

En 67-årig mand havde hentet sin 12-årige stedsøn ved en færge, men kunne ikke nå tilbage til hjemmet, hvorfor han indlogerede sig sammen med drengen på et hotel. Her onanerede han drengens kønslem og forsøgte forgæves at anbringe det i sin endetarm. Ved byretten idømt en ubetinget straf fængsel i 60 dage, som landsretten under henvisning til T.s alder og personlige forhold gjorde betinget ${ }^{26}$ ).

\section{U $1979.817 \varnothing$ :}

En 30-årig mand, der var ansat som assistent på et ungdomshjem, havde gennem et par måneder i 4 tilfælde haft samleje med 15-årig pige, der var anbragt på institutionen. Byretten mente ikke, at betinget dom kunne anvendes, når hensås til pigens alder og aldersforskellen samt forholdenes antal indenfor en kortere periode og idømte en ubetinget straf af fængsel i 40 dage. Østre Landsret forhøjede straffen til 60 dage, men ændrede til betinget straf efter det, der var oplyst om baggrunden for de strafbare handlinger (som ikke angives) og om T.s personlige forhold $\left.{ }^{27}\right)$.

\section{U 1976.96: $V$ :}

En 17-ảrig, der havde lagt sig til sengs med et pornohæfte, blev kønslig opstemt og besluttede sig til bevæbnet med en brødkniv ved nattetid at få fat $i$ en pige om fornødent ved tvang. Han mødte en 18-årig pige på gaden, som han søgte at tiltvinge sig samleje med ved at holde brødkniven mod hendes hals. Hun gjorde modstand, og da der kom en mand til, tog gerningsmanden flugten. Undervejs faldt han og standsede sin forfølger ved at true ham med brødkniven. Byretten idømte ham fængsel i 1 år 6 måneder. Kriminalforsorgen foretog personundersøgelse og foreslog, at $\mathrm{T}$ blev anbragt $\mathrm{i}$ et ungdomskollektiv, idet man frarådede anbringelse på ungdomshjem sammen med et klientel af berigelseskriminelle. $T$ havde været $\mathrm{i}$ varetægt fra pågribelsen til dommen, ialt 3 måneder, da landsretten traf sin afgørelse, som under henvisning til gerningsmandens alder og personlige forhold resulterede $\mathrm{i}$ betinget dom med vilkår om tilsyn af børne- og ungdomsforsorgen og anbringelse $\mathrm{i}$ mindst 1 år $\mathrm{i}$ en passende institution efter tilsynets nærmere bestemmelse.

\section{U 1980.62; V:}

En 15-årig svagt begavet, primitiv og umoden dreng havde i to tilfælde gjort sig skyldig i voldtægt overfor jævnaldrende piger, som han greb fat i på gaden og trak ned henholdsvis ad en skrænt og ind $\mathrm{i}$ en bevoksning, hvor han holdt ofrene fast og hindrede dem $i$ at skrige ved at holde dem for munden. I det ene tilfælde 
hindrede pigens modstand ham $\mathrm{i}$ at gennemfore samleje, men han tvang hende til at gnide pâ sit lem. Da hun fortsatte sin modstand, lagde han sin arm om hendes hals og fastholdt grebet, indtil han mærkede, at hun blev slap, hvorpå han efterlod hende $\mathrm{i}$ bevidstlos tilstand, hvorfra hun dog - uden hans viden - kort efter vågnede op. I det andet tilfælde, der blev begået $3 / 4$ senere, gennemforte han trods pigens modstand samleje.

Byretten idømte en kombinationsdom: 3 måneders fængsel ubetinget, 9 måneders betinget. Landsretten refererede, at $\mathrm{T}$ havde efterladt pigen $\mathrm{i}$ det første forhold uden at have foretaget sig noget for at sikre sig, at hun ikke frøs ihjel eller på anden måde omkom. Under hensyn til, at $\mathrm{T}$ havde gjort sig skyldige $\mathrm{i}$ to alvorlige forbrydelser mod kønssædeligheden fandt landsretten - uanset tiltaltes unge alder - ikke grundlag for at gøre nogen del af straffen bctinget, men tiltrådte strafudmålingen, fængsel i 1 år under henvisning til T.s alder og åndelige udvikling ${ }^{28}$ ).

Efter dansk procesret afhøres vidner ikke under ed, men de formanes til at tale sandhed og får at vide, at falsk forklaring er strafbar. Når det undtagelsesvis konstateres, at en vidneforklaring har været bevidst urigtig, er følgen sædvanligvis en ubetinget fængselsstraf, men undtagelser kan under særlige omstændigheder forekomme som i følgende tilfælde, der også løser et omtvistet fortolkningsspørgsmå ${ }^{29}$ ):

\section{U 1977.114 H:}

En person, der som sigtet afgiver forklaring i en straffesag, er straffri for urigtig forklaring. Ved dommen blev det statueret, at en udenforstående, der tilskynder en sigtet til at afgive falsk forklaring, ikke nyder godt af dette privilegium. Straffen, 60 dages fængsel, fandtes dog efter omstændighederne, herunder navnlig det lange tidsrum (ca. $2^{1 / 2}$ år), der var medgået til sagens behandling, at kunne gøres betinget.

I sager om brandstiftelse har der i de senere år i enkelte tilfælde været rejst spørgsmål om at anvende betinget $\operatorname{dom}^{30}$ ):

\section{U $1976.356 \mathrm{H}$ :}

En 27-årig ustraffet havde af uforklarlige grunde i spirituspåvirket tilstand anbragt en fyldt plasticpose på trappen $\mathrm{i}$ en beboelsesejendom og sat ild til posen. Bygningsskaden androg ca. $1.000 \mathrm{kr}$. Københavns byret fandt under hensyn til forholdets alvorlige karakter ikke, at der kunne anvendes betinget dom. I landsretten delte stemmerne sig. I Højesterets dom refereres, at $\mathrm{T}$ var gift og havde et lille barn og gennem flere år havde haft stabilt arbejde. 3 dommere fremhævede, at anvendelse af betinget dom normalt bør være udelukket ved lovovertrædelser af en karakter som den foreliggende. Under hensyn til de nærmere omstændigheder ved handlingen og T's personlige forhold fandt de det dog forsvarligt at idømme en betinget straf. 2 dommere voterede for ubetinget straf under hensvisning til, at ildspåsættelsen var sket $\mathrm{i}$ en beboelsesejendom. 
U 1981.21 H:

For at besvige brandforsikringen havde en 33-årig, der ikke var straffet af betydning for sagen, sat ild på sin bil til en værdi af $30.000 \mathrm{kr}$. Han havde desuden gjort sig skyldig i dokumentfalsk og bedrageriforsøg med hensyn til benzinkundekort. Efter karakteren af brandstiftelsesforholdet fandt Højesteret ikke grundlag for at gøre straffen betinget og stadfæstede nævningerettens dom på fængsel 8 måneder.

I den forløbne tid har der været rejst spørgsmål om betinget dom med hensyn til talrige andre straffelovsovertradelser. I teksten er der kun grund grund til at omtale to typer. Den ene er en kriminalitetstype, der er blevet langt mere udbredt i de senere år end tidligere, "bortførelse af børn forøvet af den af forældrene, der ikke er blevet tillagt forældremyndigheden. Det kan være sager, der er vanskelige at bedømme. Stærke - og ofte forståelige - følelser er engageret hos den skyldige og den forurettede. Hensynet til at beskytte den, der ved separationen eller skilsmissen har fået tillagt forældremyndigheden vejer tungt, men hensynet til barnet, der stadig skal opretholde forbindelsen til begge forældre, taler for at afdramatisere disse hændelser. Har unddragelsen af forældremyndigheden været kortvarig og tilbagelevering er sket frivilligt, er der sket påtalefrafald, når den krænkede ikke har ytret ønske om forfølgning. Har unddragelsen været langvarig og tilsigtet definitiv, er der idømt streng straf som det illustreres af nedenstående $\operatorname{dom}^{31}$ ):

U 1979.14 H:

Efter at forældremyndigheden over en 2-årig pige i oktober 1975 var tillagt moderen, undlod faderen under udøvelse af sin samkvemsret med barnet at bringe dette tilbage til moderen og bortførte det til Sydafrika, hvor han og barnet opholdt sig, indtil han i juni 1978 blev anholdt. Straffet med fængsel i 1 år (dissens for 6 måneder), idet betinget dom eller kombinationsdom efter forholdets beskaffenhed ikke fandtes at burde anvendes.

En anden forbrydelsestype, der i de senere år har fået forøget aktualitet i forbindelse med den øgede interesse for økonomisk kriminalitet, er åger ${ }^{32}$ ). En hyppig form er udlån mod sikkerhed i checks, der er udstedt med beløb, der ligger indenfor de grænser, som banker og sparekasser har påtaget sig. at honorere overfor checkmodtageren, selvom der ikke er dækning på kontoen. Der er dog visse undtagelser herfra, bl. a. når checkene som $\mathrm{i}$ den nedenfor omtalte sag er udstedt som »seriechecks«. 
U $1980.540 \mathrm{H}:$

To tiltalte havde over en periode på $1^{1 / 4}$ år ydet og forlænget små kortvarige lån (i reglen $1.000 \mathrm{kr}$. med en løbetid på en måned) med en rente på $20 \%$ pr. måned og mod sikkerhed i checks på hver $300 \mathrm{kr}$. Nogle af disse checks havde de ladet indløse med et tab for bankerne på ca. $11.000 \mathrm{kr}$., og for dette forhold blev de dømt for bedrageri. To andre tiltalte havde deltaget $\mathrm{i}$ virksomheden $\mathrm{i}$ et halvt år. Alle fire tiltalte havde tilsammen haft renteindtægter på henved $100.000 \mathrm{kr}$.

Ved Københavns byrets dom var de to førstnæunte tiltalte under hensyn til deres gode personlige forhold straffet med kombinationsdom, de to sidstnævnte med betinget dom. Ved landsretten blev de alle idømt ubetinget fængsel (med dissens for stadfæstelse). Også i Højesteret delte stemmerne sig. 5 dommere fandt under hensyn til overtrædelsernes beskaffenhed og omfang, at der ikke burde anvendes betinget dom og idømte de tiltalte henholdsvis 4 og 3 måneders ubetinget fængsel. 2 dommerc fandt ikke, at lovovertrædelsernes beskaffenhed eller omfang var til hinder for, at der - i overensstemmelse med nyere praksis angående anvendelse af betinget dom selv ved alvorlige forbrydelser - idømtes betingede domme i sagen. De voterede derfor for at fastsætte straffen som sket ved byrettens dom, idet de navnlig lagde vægt på ed tiltaltes gode personlige forhold og omstændighederne ved påbegyndelsen af lovovertrædelserne. Desuden skete der konfiskation af udbyttet og frakendelse af retten til at udøve eller deltage i virksomhed som pengeudlănere eller formidlere af lån.

Om valget mellem betinget og ubetinget straf ved brugstyveri ${ }^{33}$ ), returkommission $\left.{ }^{34}\right)$, uagtsomt manddrab og uagtsom betydelig legemsbeskadigel$\left.s^{35}\right)$, krankelse af meddelelseshemmeligheden $\left.{ }^{36}\right)$, afpresning ${ }^{37}$ ), fareforvoldelse $^{38}$ ), skyldnersvig $\left.{ }^{39}\right)$, „telefonbomber ${ }^{40}$ ), ulovlig tvang ${ }^{41}$ ), trusler ${ }^{42}$ ), fluglbistand $^{43}$ ), og grov skattesvig ${ }^{44}$ ) henvises til de i noterne anførte domme.

Den strafferetlige sanktion, som normalt kommer til anvendelse indenfor sarlovgivningen, er bøde. Kun få særlovsovertrædelser fører derfor til at overveje et valg mellem betinget og ubetinget straf $\left.{ }^{45}\right)$. På to praktisk vigtige områder kan det imidlertid melde sig: ved spirituskørsel under særlige omstændigheder og ved overtrædelse af narkotikalovgivningen.

Kørsel under indflydelse af spiritus førte tidligere til kortvarige ubetingede hæftestraffe, men siden begyndelsen af 70'erne har der som følge af lovændringer været anvendt bødestraf indenfor en voksende del af promilleområdet. I den betænkning fra straffelovrådet, som var udgangspunktet for at gennemføre bødestraf indenfor lavpromilleområdet, drøftes muligheden af at nærme sanktionsanvendelsen til det mønster, som følges indenfor kriminalretten $\mathrm{i}$ øvigt. Herunder omtales anvendelse af betinget dom i tilfælde, hvor afsoning af frihedsstraf vil være særlig byrdefuld, $\mathrm{f}$. eks. på grund af helbredsforhold, høj alder eller betydelig egenskade, og 
der peges på muligheden af at erstatte ubetinget frihedsstraf med betinget dom med vilkår om afvænningsbehandling, når spirituskørslen må antages at stå i forbindelse med alkoholmisbrug.

I 1974 søgte Københavns byret at bryde det vante mønster ved i nogle sager, der efter gældende praksis havde ført til kortvarige frihedsstraffe, at anvende betinget frihedsstraf kombineret med bøde og ubetinget frakendelse. I sin begrundelse henviste byretten til den udvikling, der på andre områder var sket med hensyn til udvidelse af området for betinget dom. Disse forsøg blev dog standset af landsretten (med dissens) og af Højesteret (U 1975.137 og følgende sider, kommenteret U 1975. B. 127), der henviste til, at den gældende praksis var fastlagt $\mathrm{i}$ overensstemmelse med tilkendegivelser fra Folketinget. Den seneste politiske udvikling, der har resulteret i en lovændring, der tilsiger en yderligere begrænsning i anvendelsen af frihedsstraf for at mindske antallet af afsonere, tyder på, at byretten var forud for sin tid. Derimod fulgte Højesteret i U 1972.583 betænkningens opfordring til at anvende betinget straf (i kombination med bøde) ved betydelig egenskade $\left.{ }^{46}\right)$, og landsretterne har i enkelte lidt forskelligartede tilfælde brugt betinget dom med vilkår om afvænnigsbehandling, når der forelå oplysninger, der tydede på, at alkoholistbehandling var indiceret og lovovertræderen motiveret derfor ${ }^{47}$ ).

Helbredsoplysninger som grundlag for betinget dom er kun rapporteret i en enkelt trykt afgørelse i perioden 1973-1980; det samme gælder ung alder (under 18 år), hvor det er almindeligt at begrænse reaktionen til betinget dom + bøde og frakendelse ${ }^{48}$ ).

Med hensyn til forfølgning af narkotikasager er der utvivlsomt en forskel mellem praksis i Norge, Sverige og Danmark.

Udfra det synspunkt, at lovgivningen om narkotika sigter mod at hindre udbredelse af narkotiske stoffer, medens retshåndhævelsen næppe har som opgave at modvirke eget forbrug af narkotika, der hovedsageligt forekommer at være et socialt, medicinsk problem, blev der i et cirkulære fra Rigsadvokaten i 1969 (C 144 15. 7. 1969) givet anvisning om, at strafansvar for besiddelse af narkotika til eget forbrug i reglen vil kunne afgøres af politiet med advarsel samt konfiskation. Advarsel kan også meddeles i gentagelsestilfælde, men i grovere gentagelsestilfælde, og i tilfælde af gentagen besiddelse til eget forbrug af andre stoffer end hash bør der søges pålagt bødestraf.

Retternes praksis i narkotikasager, både trykt og utrykt, er beskrevet af H. Kallehauge i U 1974 B. 228 og i en oversigt, der er udsendt af dommerforeningens informationsudvalg i. 1979. Heraf fremgår det, at salg eller bortgivelse af indtil $100 \mathrm{~g}$ hash i førstegangstilfælde medfører bødestraf, 
medens udbredelse af større kvanta som regel fører til frihedsstraf, der kun sjældent gøres betinget. Udbredelse af hårde stoffer fører som regel til ubetinget straf, medmindre mængderne er ganske små (f. eks. under $1 \mathrm{~g}$ morfinbase), eller andre særlige grunde, herunder specialpræventive hensyn taler for at foretrække betinget dom. Fra trykt praksis om valget mellem betinget og ubetinget straf $\mathrm{i}$ den undersøgte periode anføres følgende to domme $\left.^{49}\right)$ :

\section{U $1973.348 \mathrm{~V}$ :}

19-årig ustraffet havde over en periode på $1 / 2$ år købt 130 nålehylstre morfinbase (godt $100 \mathrm{~g}$ ) for godt $8.000 \mathrm{kr}$. For at financiere sit forbrug havde han videresolgt omkring halvdelen heraf med en fortjeneste på noget over $2.000 \mathrm{kr}$. Han var nu ophørt med sit narkotikaforbrug og kommet under ordnede forhold. Af specialpræventive grunde fandtes han at kunne idømmes en betinget straf af fængsel i 6 måneder med tilsyns- og særvilkår. Fortjenesten blev inddraget.

\section{U $1976.791 \varnothing:$}

Over en periode på omkring $1 / 2$ år havde en hustru ad flere gange under fængselsbesøg hos sin ægtefælle, der afsonede en straf på fængsel i 9 år, indsmuglet ialt $775 \mathrm{~g}$ hash. Hun modtog penge hertil fra ægtefællen. Hun blev opdaget, da hun forsøgte at indsmugle yderligere $240 \mathrm{~g}$. Ægtefællen havde fra anden kilde modtaget $135 \mathrm{~g}$ hash. Af den samlede mængde, som han havde modtaget, $910 \mathrm{~g}$, havde han til medfanger videresolgt $250 \mathrm{~g}$, og det lagdes ved dommen til grund, at videresalget var sket til samme pris, som han selv havde betalt. Begge blev straffet efter lov om cuforiserende stoffer, og hustruen blev anset med betinget dom, medens ægtefællen blev idømt fængsel 6 måneder ubetinget.

Adresse:

Per Lindegaard

Rigsadvokat Per Lindegaard

Porthusgade 3

DK 1213 Kobenhavn K.

\section{N O T E R}

Af hensyn til danske praktikere gives der i noterne udtommende henvisninger til afgørelser om valget mellem betinget dom og ubetinget dom for overtrædelse af borgerlig straffelov og særlovgivningen fra U 1973.393 til udgangen af U 1980. $(\mathrm{U}=$ Ugeskrift for Retsvæsen. $\mathrm{H}$ er højesteretsdom, $\varnothing$ betyder $Ø$ stre Landsret, $\mathrm{V}$ Vestre Landsret og $U$ efter dommen, at den er afsagt af en byret).

1) Nordisk utredningsserie A 1980:13, s. 9-14.

2) NTfK 1970. $221 \mathrm{ff}$.

3) Forskydningen mellem andelen af bøder og påtalefrafald må bl. a. antages at have forbindelse med, at sager om mindre berigelsesforbrydelser $(\$ 287)$ ved 1. 224 7.6. 1972 blev henlagt under politimestrenes kompetence; herefter afgøres størstedelen af disse sager med bøde(forelæg), jfr. Anklagemyndighedens Ârrsberetning 1974, s. 1. 
4) Om bcgrundelsen for denne praksis henvises til Ugeskrift for Retsvæsen 1970 B. $176-177$.

5) Reguleringspristallet i januar $1971=100$, var i juli 1973 steget til 120 og i januar 1980 til 145,5 efter at have været nulstillet $\mathrm{i}$ januar 1975, således at stigningen med udgangspunkt $\mathrm{i}$ januar $1971=100$ er 214.

6) Betinget dom for arbejdspladstyveri desuden i U $1973.750 \mathrm{~V}$ (+ bøde); U 1974.431 Ø (50.000 kr., genoprettet, 21-årig + tilsyn); U 1975.1101 V (30.000 kr., tidligere straffet, varetægt 6 uger + tilsyn). Ej betinget dom i U 1977.342 V (65.000 kr. incl. underslæb). Ligeledes U 1979.260 Ø (27.000 kr.) og U 1979. $704 \mathrm{H}$ (108.000 kr.). Kombinationsdom anvendt i U $1973.575 \mathrm{~V}$ (rengøringshjælp, der havde beholdt nøgle $-55.000 \mathrm{kr}$.); U 1975.322 Ø (medicinalvarer til ca. $30.000 \mathrm{kr}$.).

7) Norsk Straffelov $\S 258$ og svensk Brottsbalk kap. $8 \S 4$ (der nu ikke længere medtager indbrud som kendetegn).

8) Anklagemyndighedens Ärsberetning 1974. $16 \mathrm{ff}$.

9) Se endvidere om indbrudstyveri: U $1973.515 \mathrm{H}$ (ej betinget dom; 11 forhold); U $1973.575 \mathrm{~V}(55.000 \mathrm{kr}$. - kombinationsdom); U $1974.589 \mathrm{~V}(4.800 \mathrm{kr}$. — begået under orlov, men på domstidspunktet prøveudskrevet - betinget dom + tilsyn); U 1974.821 Ø (to forudgående betingede domme, nu tyveri af 3 kasser øl - betinget dom + bøde + tilsyn); U $1974.846 \varnothing$ (17 år, tidligere tiltalefrafald - bl. a. indbrud i guldsmedeforretning (til ca. $150.000 \mathrm{kr}$.) sammen med andre - varetægt 7 uger - betinget dom + tilsyn); U $1975.672 \varnothing$ (17 år - adskillige tyverier, hærværk, brugstyveri $\mathrm{m}$. v. begået $\mathrm{i}$ prøvetiden for en betinget dom for bl. a. røveri - betinget fællesstraf 2 år + tilsyn og særvilkår, herunder beskæftigelse på skonnerten »Fulton«); U $1977.775 \varnothing$ (ej betinget dom - tyveri af bil til $45.000 \mathrm{kr}$. - pågrebet på vej ud af landet); U 1980.674 Ø (indbrud - $250 \mathrm{kr}$. - ej $\$ 287$, men betinget dom); U $1980.794 \mathrm{~V}$ (se note 30 ).

Om andre tyverier: U $1974.197 \mathrm{~V}$ (redskaber fra gårde til $14.500 \mathrm{kr}$. - betinget dom + bøde); U $1974.212 \mathrm{~V}$ (brugstyveri og mindre tyveri fra biler betinget hrefte); U 1974.226 V (flere gange straffet berigelseskriminel - efter prøveløsladelse konstateret kriminalitet forud for sidste dom - betinget tillægsstıaf).

10) Andre domme om underslæb: U $1974.243 \varnothing(44.000 \mathrm{kr}$. — delvis genoprettet betinget dom): U $1974.434 \varnothing(80.000 \mathrm{kr}$. - ej betinget dom); U $1974.620 \varnothing$ $(50.000 \mathrm{kr}$. - delvis genoprettet - tab af tjenestemandsstilling - betinget dom); U 1974.628 (ligel. — 9.000 kr.); U 1974.1036 V $(70.000 \mathrm{kr}$. - ej betinget dom); U $1975.2 S 9 \varnothing(115.000 \mathrm{kr}$. - delvis genoprettet - svigtende kontrol - betinget dom); U $1976.58 \mathrm{H}$ (kvindelig bankkasserer - $65.000 \mathrm{kr}$. - genoprettet - ej betinget dom, men dissens); U $1976.228 \varnothing(128.000 \mathrm{kr}$. - delvis genoprettet - ej betinget dom); U $1976.237 \varnothing(69.000 \mathrm{kr}$. - tab af tjenestemandsstilling - betinget dom); U $1977.86 \mathrm{H}(45.000 \mathrm{kr}$. + dokumentfalsk og bedrageri - delvis genoprettet - ej betinget dom); U $1977.167 \mathrm{~V}(90.000 \mathrm{kr}$. - ej betinget dom); U 1977.342 V (anført i note 6); U $1977.344 \mathrm{~V}(63.000 \mathrm{kr}$. + dokumentfalk og skattesvig - underslæbet genoprettet - ej betinget dom).

11) U $1973.743 \mathrm{~V}(7.000 \mathrm{kr}$. - genoprettet - betinget dom); U $1973.1006 \varnothing$ (9.000 kr. - betinget dom); U $1974.254 \varnothing(8.000 \mathrm{kr}$. - skærpende omstændigheder par - manden ubetinget straf, kvinden kombinationsdom); U $1974.440 \varnothing$ (7.600 $\mathrm{kr}$. - genoprettet - betinget dom + bøde); U $1975.640 \mathrm{~V}(12.000 \mathrm{kr}$. - genoprettet, særlige forhold - betinget dom); U $1976.166 \mathrm{H}(41.000 \mathrm{kr}$. - ej betinget dom); U $1976.868 \varnothing(23.000 \mathrm{kr}$. - delvis genoprettet, særlige forhold betinget dom); U $1977.901 \varnothing(27.000 \mathrm{kr}$. - betinget dom under henvisning til (uoplyste) personlige forhold); U $1979.1063 \mathrm{~V}$ (Student - $9.000 \mathrm{kr}$. - cj betinget dom). 
12) Foruden de refererede domme henvises til U $1979.529 \mathrm{H}$ (falsk anmeldelse og forsikringsbedrageri til $22.000 \mathrm{kr}$. - ej betinget dom). Om bedrageri $i$ ovrigt henvises til følgende domme: U $1973.636 \mathrm{H}(16.000 \mathrm{kr}$. - benzinkreditkort + dokumentfalsk - ej betinget dom); U 1974.266 V (ladet en anden møde til blodprove i faderskabssag - falsk legitimation - ej betinget dom); U 1974. $619 \varnothing$ (5.000 kr. - urigtig faktura - ej genoprettet - ej betinget dom); U $1974.952 \varnothing$ (16.700 kr. - kontoovertræk - ej betinget dom); U $1976.449 \varnothing$ $(7.500 \mathrm{kr}$. - forsøg - funktionærforhold - betinget dom); U $1976.604 \varnothing$ (214.000 kr. - gireringsfejl - ej betinget dom).

13) Andre dokumentfalskdomme, der tager stilling til valget mellem betinget og ubetinget straf: U $1973.998 \mathrm{~V}$ (falske bilinspektionsgodkendelser - ej betinget dom); U 1974.266 V (§ 174 - anført i note 12); U 1974.845 Ø (falsk afgiftsfritagelsesansøgning $-21.000 \mathrm{kr}$. - genoprettet - kombinationsdom); U $1975.433 \mathrm{~V}$ (kontrakter, afgiftssvig - $1.700 \mathrm{kr}$. - betinget dom); U 1975.653 V (kørselstilladelse - betinget dom + bøde); U 1975.889 Ø (falsk kvittering, falsk forklaring - ej betinget dom); U 1976.862 Ø (falske underskrifter på stillerliste til valg — betinget dom); U $1977.775 \varnothing$ (checkfalsk og bedrageri $208.000 \mathrm{kr}$. - ej betinget dom); U 1977.1049 Ø (falske postkvitteringer - forberedelse til skattesvig - $1.000 \mathrm{kr}$. - betinget dom + bøde); U $1978.215 \mathrm{~V}$ (\$ 173 - $20.000 \mathrm{kr}$. - ej betinget dom); U $1979.827 \varnothing$ (falsk erklæring til brug ved erhvervelse af frakendt førerret - ej betinget dom); U $1980.426 \mathrm{~V}$ (falsk attest til brug ved ansøgning om opholdstilladelse - betinget dom).

14) U $1973.750 \mathrm{~V}$ (køb i få tilfælde til små værdier - opbevaring m. v. af koster til ca. $8.000 \mathrm{kr}$. - desuden arbejdspladstyveri til $1.600 \mathrm{kr}$. — betinget dom + bøde); U $1977.376 \varnothing$ (hjælp til afsætning af koster til ca. $7.000 \mathrm{kr}$. - betinget dom + bøde); U $1977.596 \varnothing$ (videresalg i forretning af varer til ca. $40.000 \mathrm{kr}$. - ej betinget dom); U $1979.676 \varnothing$ (køb og salg af guldsmykker til værdi $137.000 \mathrm{kr}$. - cj betinget dom); U $1980.429 \mathrm{~V}$ (hæleri med hensyn til stjålet checkblanket og falsk underskrift - $500 \mathrm{kr}$. - betinget dom).

15) En del af de forhold, der anmeldes som røveri, må antages ved en nærmere prøvelse at vise sig alene at være tyveri eller tyveri og vold.

16) Anklagemyndighedens Årsberetning 1977. 42.

17) U $1974.160 \mathrm{H}$ (tegnebog med $530 \mathrm{kr}$. fra 72-årig - ej betinget dom); U 1974. $840 \varnothing$ ("rulleforretning $-200 \mathrm{kr}$. -2 19-årige, den ene tidligere straffet, den anden ustraffet - varetægt 5 uger - den ustraffede betinget dom, den anden ej betinget dom); U $1974.1060 \varnothing$ (16-årig - tillige tyverier, ialt 100.000 $\mathrm{kr}$. -- ej betinget dom); U $1975.759 \mathrm{H}$ (15 år tidligere straffet -2 banderøverier og 3-4 forsøg på røveri overfor forbipasserende samt tyverier — ialt $200 \mathrm{kr}$. - ej betinget dom); U $1975.761 \mathrm{H}$ (som foran - 4 røverier - ustraffet - lokal bandehærgen - ej betinget dom); U $1976.878 \varnothing$ (17 år, ustraffet - forsøg med luftpistol i bagerforretning samt 6 indbrud - ej betinget dom); U $1976.919 \mathrm{H}$ itidligere straffet - »rulleforretning « samt hæleri $-1.500 \mathrm{kr}$. — ej betinget dom); U $1977.166 \mathrm{~V}$ (forsøg i forretning - maskinpistol i taske - ringe fasthed $\mathrm{i}$ forsættet - gode personlige forhold - kombinationsdom med tilsyn); U 1977.261 H (atypisk røveriforhold samt ulovlig tvang - betinget dom for 1 af 3 deltagere på grund af ringe medvirken); U 1977.1054 Ø tidligerc straffet — »rulleforretning « - $140 \mathrm{kr}$. - ej betinget dom); U $1978.739 \varnothing$ (17-årig - pistolattraprøveri i konditori samt narkotikaovertrædelse - kombinationsdom); U $1979.681 \varnothing$ (forsøg - sparekasse — 36-årig kvinde - ej betinget dom); U 1979.689 Ø (18-årig - 2 røverier overfor samme kebmand med luftpistol - $5.000 \mathrm{kr}$. - ej betinget dom).

18) Ikke i Folketingets Retsudvalgs betænkning som anført i Anklagemyndighedens Årsberetning 1977. 8. 
19) Landsretspraksis i voldssager er gennemgået i Anklagemyndighedens Årsberetning 1977. $7 \mathrm{ff}$ og af $\mathrm{H}$. Kjær $\mathrm{i}$ en oversigt (nr. 3) fra dommerforeningens informationsudvalg.

20) Der foreligger i øvrigt nedenstående afgørelser om betinget dom i voldssager siden redegørelsen i U 1973 B. 137: U 1974.611 V (vold med skade til følge overfor ikke sagesløs - betinget dom, betinget af erstatningsbetaling); U 1974.845 Ø (vold med skade til folge overfor 2-årigt dagplejebarn - ej betinget dom); U $1975.876 \varnothing$ (vold mod sagesløs - betinget dom + bøde $1.000 \mathrm{kr}$.); U $1975.1132 \varnothing$ (17-årig - vold mod sagesløs med skade til følge - ej betinget dom); U 1976.236 Ø (vold mod tjenestemand - 19-årig - ej betinget dom); U 1976.555 H (kvælertag på kæreste, der var sagsløs - ej betinget dom); U $1977.190 \varnothing$ (vold mod og forulempelse af tjenestemand - ej betinget dom); U $1977.1009 \mathrm{~V}$ (vold af særlig rả og brutal karakter mod spædbarn - gode personlige forhold - varetægt 3 uger — betinget dom); U 1978.1006 Ø (18 år

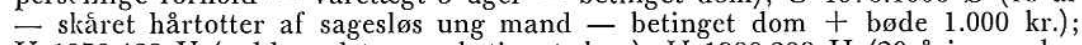
U 1979.428 V (vold mod tyv - betinget dom); U 1980.208 H (20-årig - slag med hånden - mindre skade på 15-årig - ej betinget dom).

21) Sexuella övergrepp, Sexualbrottsutredningen, SOU 1976:9; betænkning 747/75 fra Straffelovrådet.

22) 1. 195 28.4. 1976.

23) Straffelovrådets betænkning $914 / 1980$, som har dannet grundlag for en omskrivning af reglerne om voldtægt ved 1. 256 27.5.1981.

24) I de efterfølgende noter er domme om sædelighedsforbrydelser rubriceret efter karakteren af forbrydelsen i tilslutning til de domme, der refereres i teksten. Udover de der anførte domme er der taget stilling til spørgsmål om betinget dom i følgende sager:

U 1975.889 Ø (mellemmand ved erhvervsmæssig utugt ved værelsesudlcining - betinget dom + bøde); U $1977.840 \mathrm{H}$ (bordelvirksomhed - ej betinget dom); U $1978.64 \mathrm{H}$ (ligeledes); U $1978.765 \varnothing$ (alfonseri - ej betinget dom).

25) Samleje med mindreårige i øvrigt: U 1973.393 Ø (under tvang (\$ 217) samleje med 14:4-årig steddatter - ej betinget dom); U $1976.964 \mathrm{~V}$ (2 7-8-årige piger - ej betinget dom); U $1977.807 \varnothing$ (6-årig - kombinationsdom); U 1980. $467 \varnothing$ (30-årig - knapt 15-årig pige - ej betinget dom); betinget dom i U $1978.581 \varnothing$ (samleverskes 13-årige datter) og U $1980.819 \varnothing$ (68-årig, opmuntret).

26) Betinget dom for strafbare forhold overfor drenge ligeledes i U $1975.881 \varnothing \mathrm{og}$ U 1980.1091 Ø; men ved forhold, der har været længerevarende, ubetinget straf: U 1975.1111 V, eller kombinationsdom: U $1976.868 \varnothing$ og U $1979.957 \varnothing$.

27) $\mathrm{Om}$ betroelsestilfælde henvises udover det $\mathrm{i}$ note 25) anførte yderligere til: U $1974.389 \varnothing$ (forpraktikant på børnehjem - 17-årig pige - betinget dom); U 1975.1007 Ø (forstander på ungdomshjem, afskediget - 15-årig pige længerevarende - ej betinget dom); U $1977.567 \mathrm{~V}$ (medarbejder på ungdomspension - 15-årig pige - betinget dom); U 1979.427 V (fangselsbetjent kvindelig arrestant — afskediget — betinget dom); U $1979.817 \varnothing$ (assistent på ungdomshjem - 15-årig pige - betinget dom).

28) Om voldtægt og voldtægtslignende forhold se udover den i notc 25) nævnte U $1973.393 \varnothing$ desuden: U $1976.960 \mathrm{~V}$ (M havde under medvirken af $\mathrm{K}$ voldtaget 19-pige. Betinget dom til K, ubetinget til M); U $1977.867 \mathrm{~V}(17 \stackrel{\mathrm{r}}{\mathrm{r}}-$ voldtægt overfor 210 -årige - ej betinget dom); U $1978.762 \varnothing$ (\$218, stk. 2 ubetinget dom); U $1980.627 \mathrm{~V}$ (15-årigs grove voldtægtshandlinger over for jævnaldrende piger - ej betinget dom).

29) Om falsk forklaring for retten og falsk anmeldelse og urigtig erklaring, se i øvrigt følgende domme. Ubetinget straf: U 1974.1061 Ø (19-årig i spiritussag); U 1975.889 Ø (tvangsauktion + falsk kvittering); U 1976.388 H (spiritussag): U 1976.417 V (2 19-årige i spiritussag); U 1976.754 V (\$ 159, stk. 2 og $\$ 164$, 
stk. 3); U 1978.233 Ø (falsk anmeldelse); U 1978.412 Ø (24-årig kvinde i faderskabssag). Betinget dom anvendt $\mathrm{i}$ den under forsikringsbedrageri refererede dom U 1975.1062 H samt i: U 1976.767 Ø (urigtig erklæring under indsættelsesforretning) og U 1979.190 (falsk forklaring og falsk anmeldelse - begge 19 år). Om urigtig erklæring i forbindelse med bigami foreligger en række domme, U 1974.1067 Ø, U 1975.1117 V og U 1977.1007 V, der alle resulterer i ubetinget straf, medens $\mathrm{U} 1975.982 \mathrm{~V}$, hvor der var varetxgt i 4 uger, endte med betinget dom. Om urigtig erklæring i forbindelse med socialbedrageri henvises til note 11).

30) U 1976.780 Ø (brandstiftelse i beboelsesejendom - ej betinget dom); U 1977. $198 \varnothing$ (lignende sag som i den refererede U 1981.21 H - ej betinget straf); $\mathrm{U} 1979.712 \mathrm{H}$ (beboelsesejendom - ej betinget straf); U $1980.519 \mathrm{H}$ (fabrik, bygningsskade ca. 2 mill., løsøre 1,6 mill. - fangsel 2 år, men dissens for under henvisning til T's personlige forhold - ganske undtagelsesvis at idømme 3 års fængsel betinget); U $1980.925 \mathrm{~V}$ (kombinationsdom, 22 og 18 år, sommerhus, skade $15.000 \mathrm{kr}$.). Andre almenfarlige forbrydelser: U $1975.1002 \varnothing$ ( $\$ 184$ - 20-årig havde sammen med en anden skubbet en terpentintromle ud foran en bil - betinget dom + bøde); U 1978.816 H (\$ 183 - 20-årig og 23-årig forvoldt sprængning af hjemmelavet bombe i rutebilgarage - skade 480.000 kr. - ej betinget dom). Harvark: U $1977.201 \varnothing$ (24-årig opskåret dækkene på ca. 100 biler - ej betinget dom); U 1980.794 V (3 18-20-årige havde stjålet spraydåser med maling og oversprøjtet udstillingsvinduer og biler - skade ca. $16.000 \mathrm{kr}$. - ej betinget dom); U 1980.1081 Ø (2 16-årige affyrede haglskud med luftbøsser med risiko for personskade og knuste ruder til $200 \mathrm{kr}$. til følge - betinget dom + bøde).

31) Om overtrædelse af straffelovens $\$ 215$ se tillige U $1976.609 \varnothing$ (tilskyndet faderen til at fjerne barn fra moderen og anvist opholdssted - ej betinget
dom).

32) U $1976.638 \varnothing$ (åger ved ejendomskøb af plejehjemspatient, hvor én af de tiltalte var ansat - betinget dom). U 1980.845 Ø (lignende sag som U 1980.340 - ej betinget dom).

33) U $1974.226 \mathrm{~V}$ (17-årigs spirituskørsel uden forerbevis i brugsstjålet vogn, der blev totalskadet - betinget dom + frakendelse); U $1974.599 \mathrm{~V}$ (tidligere flere gange straffet for spirituskørsel - nu brugstyveri og påny spirituskørsel betinget dom med afvænningsvilkår); U $1975.867 \mathrm{~V}$ (lignende sag som $U$ 1974.226 V + bøde).

34) U $1974.955 \varnothing$ (skjult agentprovision på $200.000 \mathrm{kr}$. - betinget dom, bl. a. under henvisning til tiden).

35) U $1975.314 \varnothing$ (under bilkørsel voldt uagtsomt manddrab og betydelig legemsskade på grund af søvnmangel - egen alvorlig tilskadekomst - betinget dom); U 1980.755 U (3 16-årige havde ladet deres urin i en benzintank på et fly og derved forårsaget nødlanding med varigt mén for piloten - tillige dømt for fareforvoldelse efter $\$ 252-$ betinget dom).

36) U $1975.380 \mathrm{H}$ (optaget udtalelse fra lukket møde med skjult mikrofon - ej betinget dom); U $1976.186 \mathrm{~V}$ (udlevering af brev med blodprøve i spiritussag - betinget dom).

37) U $1975.656 \mathrm{~V}$ (afpresning overfor kunder, der var grebet i butikstyveri - betinget dom + bøde).

38) U $1975.695 \varnothing$ (ført bil ind over fortov for at forskrække fodgængere - ej betinget dom); U 190.755 U (anført i note 35)); U 1980.821 Ø (fareforvoldelse ved at bringe sprængstof til sprængning - egen tilskadekomst - ej betinget dom); U $1980.1081 \varnothing$ (anført i note 30$)$ ).

39) U $1978.750 \varnothing$ (anført i teksten vedrørende underslæb); U $1980.468 \varnothing$ (solgt TV-apparat, som der var gjort udlæg i - betinget dom). 
40) U $1975.696 \varnothing$ (4 telefoniske meddelelser til fabrik om ikke-eksisterende bomber - særlige forhold - betinget dom); U 1977.1062 Ø (meddelclse om ikkeeksisterende bombe til politiet - ubetinget straf); U $1978.355 \mathrm{H}$ (i en periode med telefonboksbombeterror havde 2 17-årige anbragt attrapbomber i telefonboks - ej betinget dom).

41) U $1975.1143 \varnothing$ (grebet fat i kvinde og væltet hende, men ikke bevis for uterlig hensigt - ej betinget dom).

42) U $1976.442 \varnothing$ (sigtet på politibetjente med haglgevær - ej betinget dom).

43) $\mathrm{U} 1977.713 \mathrm{H}$ (bistand til fangeflugt - ej betinget dom).

44) U 1980.1095 Ø (unddraget skat ca. $400.000 \mathrm{kr}$. - ej betinget dom).

45) U $1976.978 \mathrm{~V}$ (dyreværnsloven - betinget dom + bøde); U $1978.404 \varnothing$ (spiritusaf giftsloven - betinget dom + rettighedsfrakendelse).

46) Indenfor den undersøgte periode endvidere: U $1973.753 \mathrm{~V}, \mathrm{U} 1977.362 \mathrm{~V}$ og U $1980.236 \mathrm{~V}$.

47) Indenfor den undersøgte periode: U $1973.990 \mathrm{~V}, \mathrm{U} 1974.380 \mathrm{~V}, \mathrm{U} 1974.599 \mathrm{~V}$ tillige brugstyveri), U $1975.1100 \mathrm{~V}$. I U $1980.199 \mathrm{H}$ var $\mathrm{T}$ ophørt med sit spiritusmisbrug, og der fandtes ikke tilstrækkeligt grundlag for at gøre straffen beting et.

48) U $1975.305 \varnothing$ (depressionsanfald); U $1975.1008 \varnothing$ (17-årig pige).

49) U $1973.630 \varnothing$ (køb af $11-12 \mathrm{~g}$ morfinbase til eget brug - betinget dom); U 1974.613 Ø (solgt $1,2 \mathrm{~g}$ morfinbase - ej betinget dom); U 1979.1084 Ø (videreforhandling af ialt $2,5 \mathrm{~kg}$ hash - ubetinget fængsel 4 måneder). 